\title{
Mediator of RNA Polymerase II Transcription Subunit 27
}

National Cancer Institute

\section{Source}

National Cancer Institute. Mediator of RNA Polymerase II Transcription Subunit 27. NCI

Thesaurus. Code C28691.

Mediator of RNA polymerase II transcription subunit 27 (311 aa, $\sim 35 \mathrm{kDa}$ ) is encoded by the human MED27 gene. This protein is involved in the transcriptional regulatory activity of the mediator protein complex. 